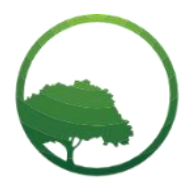

Research in Business \& Social Science

IJRBS VOL 10 NO 5 ISSN: 2147-4478

\title{
A critical study of the Job Creation Law No.11 of 2020 and its implications for labor in Indonesia
}

D Adnan Hamid

\author{
A R T I CLE INFO \\ Article history: \\ Received 18 June 2021 \\ Received in rev. form 25 July 2021 \\ Accepted 27 July 2021 \\ Keywords: \\ Job Creation Law No.11 of 2020, \\ Labor, Labor Law, Preamble and the \\ 1945 Constitution, Indonesia \\ JEL Classification: \\ O58, P36
}

\begin{abstract}
A B S T R A C T
This study aims to examine the Job Creation Law No. 11 of 2020 which contains the interpretation, position and implications of the Act on employment in Indonesia. The research method used is normative legal research, and the findings of the research are the Job Creation Law No. 11 of 2020 is considered to have tended to ignore labor rights. This law was formed and ratified as a labor law, which is still considered far from the wishes of the people who adhere to democratic principles. This is due to the lack of optimal community involvement in the drafting process so that this law has very implications for workers. For example, workers do not have a strong bargaining position in labor law in Indonesia. Therefore, it is necessary to develop a manpower law that is in line with the mandate of the Preamble and the 1945 Constitution as a basis for the government and parliament in making laws and regulations and at the same time providing legal protection, especially for workers or laborers and employers simultaneously in order to create a society that is prosperous, and evenly distributed both materially and spiritually.
\end{abstract}

(C) 2021 by the authors. Licensee SSBFNET, Istanbul, Turkey. This article is an open access article distributed under the terms and conditions of the Creative Commons Attribution (CC BY) license (http://creativecommons.org/licenses/by/4.0/)

\section{Introduction}

In Indonesia, the main problem today is the inability of the government to prepare and absorb the number of labors, and the private sector has also not been able to absorb all existing job seekers (Sesa,2016;3). Furthermore, one of the things related to the lives of many people according to the 1945 Constitution of the Republic of Indonesia (UUD 1945) is the right to work and a decent life. According to the 1945 Constitution, Article 27 paragraph (2) states that: "Every citizen has the right to work and a decent living for humanity", and Article $28 \mathrm{D}$ paragraph (2) states that "Everyone has the right to a decent job and livelihood". receive compensation and fair and proper treatment in an employment relationship". The two articles have very broad implications for the government, because these norms position the government in order to provide decent work opportunities for every Indonesian citizen (Warga Negara Indonesia/WNI), and provide legal protection for every Indonesian citizen in doing work, whether working in the government. as well as in the private sector. With regard to decent work and providing legal protection for every worker. André (2019:7) states that the mandate of the International Labor Organization (ILO) has always been solid in fighting for social justice and employment. as a means to achieve lasting peace in an era where most of the world is in conflict so that the existence of legislation is very important because it can provide legal certainty. In this regard, the government seeks to answer problems in the manpower sector by enacting the labor law, the Job Creation Law No.11 of 2020 (JCL No.11/2011).

According to the Job Creation Law No.11 of 2020 (JCL No. 11/2011) Article 1 (1), what is meant by Job Creation is an effort to create jobs through efforts to facilitate, protect, and empower cooperatives and micro, small and medium enterprises, improve the investment ecosystem and ease of doing business, and investment from the Central Government and acceleration of national strategic projects. JCL No. 11/2020 was officially ratified in the plenary meeting of the Indonesian People's Representative Council (DPR RI) on October 5, 2020. JCL No. 11/2020 was signed by the President of the Republic of Indonesia, Joko Widodo on November 2, 2020 as many as 1,187 pages, and the regulation is numbered Law Number 11 of 2020 concerning Job Creation in the State Gazette

* Corresponding author. ORCID ID:

(C) 2021 by the authors. Hosting by SSBFNET. Peer review under responsibility of Center for Strategic Studies in Business and Finance. https://doi.org/10.20525/ijrbs.v10i5.1271 
(Lembaran Negara/LN) 245 and Supplementary No.to the State Gazette of the Republic of Indonesia (Tambahan Lembaran Negara Republik Indonesia/TLNRI) 6673. However, the law continues to cause polemics among the wider community both from academics, community organizations, labor organizations, local governments, students and various other interest groups because the people feel they have been fooled, left behind, and have not responded well to their aspirations (Komarudin, 2020).

According to Nukhbatul and Aep (2021), there are regulations that are not abolished in JCL No 11/2020, but are conceptually changed so that they can have implications for other conflicts, especially regarding the rights of local workers who are Indonesian citizens. which must be protected by law on the basis of justice. Therefore, the core problem in this research is that JCL No.11/2020 is considered to tend to ignore workers' rights. Notonagoro (2015) states that the notion of rights is the power to accept or do something that should be accepted or done solely by certain parties and cannot be done by other parties which in principle can be demanded by them by force. Rights and obligations are something that cannot be separated, but there are conflicts because rights and obligations are not balanced. In fact, every citizen has the right and obligation to get a decent living, including wages. Wages have a very important and important meaning and significance for workers/laborers, entrepreneurs, government and society in general. But in reality, there are still many people who do not feel the welfare in living their lives.

The crucial issue related to JCL No. 11 of 2020 is after the joint approval by the DPR and the President at the Plenary Meeting, the substance of the draft of the Job Creation Bill cannot be changed. It is regulated in Article 72 of Law no. 15 of 2019 concerning Amendments to Law no. 12 of 2011 concerning the Establishment of Legislation. But in reality, the substance of the Job Creation Bill was changed, both when it was still in the DPR and after it was submitted to the President (Pusat Studi Hukum dan Kebijakan Indonesia /PSHKI, 2020). The issue of JCL No.11/2020 was widely opposed and rejected by the wider community because the preparation process starting from planning, discussing and ratifying and being passed into law was considered by the wider community that these ordinances tended not to accommodate community participation, and the lack of involvement society so that many parties feel disadvantaged, the articles on employment are considered detrimental to the workers/labors (Supriyatna \& Fauzi,2020).

Based on various descriptions of these problems and referring to several preliminary studies, this research aims as follows: (1) What is the Interpretation and urgency of the Job Creation Law Number 11 of 2020 for the labor in Indonesia?, and (2) What is the position of the labor in Indonesia in the Job Creation Law Number 11 of 2020?,and (3) What are the implications of the Job Creation Law Number 11 of 2020 for the labor in Indonesia? Thus, this study investigates, examines, and seeks to answer the topic and research specifications, namely: "A critical study of the Job Creation Law No.11 of 2020 and its implications for labor in Indonesia". The Manpower Law Number 13 of 2003 concerning Manpower (Manpower Law No. 13/2003) and the Job Creation Law Number 11 of 2020 (JCL No. 11/2011) as the Manpower Law applicable in Indonesia are the subject of this research study. The study was carried out comprehensively including the interpretation and urgency, the positioning of the workforce, and the implications of JCL No.11/2020 for labor in Indonesia such as: (a) foreign workers (Tenaga Kerja Asing/TKA), (b) certain time work agreements (Perjanjian Kerja Waktu Tertentu/PKWT), (c) outsourcing, (d) working time, (e) wages, (f) termination of employment (Pemutusan Hubungan Kerja/PHK), (g) social security and severance pay.

Furthermore, there are three things that are raised in this study, especially those regulated in Chapter IV of JCL No.11/2020. This law has amended four laws as follows: (a) Manpower Law No. 13 of 2003 concerning Manpower (Labor Law 13/2003), (b) Law Number 40 of 2004 concerning the National Manpower Security System (Law No. SJSN), (c) Law Number 24 of 2011 concerning the Social Security Administering Body (UU BPJS), and (d) Law Number 18 of 2017 concerning the Protection of Indonesian Migrant Workers (UU PPMI). The following article discusses systematically the interpretation, position of workers in labor laws in Indonesia, and the implications of JCL 11/2020 for workers in Indonesia. This is the element of the novelty of the research when compared to the results of the three previous studies and as the state of the art of this research. The research method used is normative legal research, reviewing library materials or secondary data (Soekanto \& Mamudji, 2003:13) in order to answer the legal problems faced (Marzuki, 2010:35) as stated in the legislation or norms that are the object of rejection. measure that is considered appropriate (Amiruddin \& H. Zainal, 2006: 118). by using qualitative data.

According to Keirl and Miller in Moleong (2004), qualitative research is a particular tradition in the social sciences which basically relies on observations in language and terminology (Moleong,2004:131) as well as data sources used in research. This research is secondary data in the form of primary legal materials, secondary legal materials While the data collection technique used is library analysis to find out theories, methods and approaches that can be studied related to the problems in this research through the study of various legal principles related to labor law issues in the form of systematics and logic. Primary legal materials consist of laws and regulations that are sorted by hierarchy (Marzuki,2006:141) and are authoritative in the form of laws and regulations related to labor laws, including the 1945 Constitution of the Republic of Indonesia, Manpower Law No. 13/2003, and JCL No. 11/2020 . Secondary legal materials consisting of textbooks, legal journals, and the results of the latest symposiums related to the research topic (Ibrahim,2008:295).

\section{Interpretation and urgency of Job Creation Law No. 11 of 2020}

Job Creation Law No. 11 of 2020 (JCL No.11/2020) deregulates many fields using the omnibus law technique. In the context of legal science, omnibus law is a law whose substance is to revise and/or repeal many laws, and this concept has developed in common law 
countries with an anglo saxon legal system such as the United States, Belgium, England and Canada (Antoni,2020 in Kukuh \& Sukarmi,2020:191). The concept of the omnibus law offers solutions to problems caused by too many overlapping regulations and rules (Hamid,2020:191).Garner, et.al (Eds.) in Black's Law Dictionary (2009: 186) in Hamid (2020), the omnibus bill interpretation has the following meanings: (a) A bill containing a variety of different things, usu. designed in this way to force the executive to accept all minor unrelated terms or to veto major terms;and (b) bills that deal with all proposals related to a specific subject, such as "omnibus judicial bills" which include all proposals for new judgeships or "omnibus crime bills" dealing with different subjects such as new crimes and grants to states for crime control. Thus, the use of the concept of the omnibus law, the omnibus bill seems to be able to answer various problems related to laws and regulations that overlap in Indonesian law in general and especially in labor law (Hamid,2020:191).

Job Creation Law no. 11 of 2020 (JCL No.11/2020) does not necessarily abolish the Manpower Law No.13/2003. This means that the provisions in the Manpower Law 13/2003 that are not listed in JCL No.11/2020 are still considered valid as stipulated in JCL No.11/2020 article 81. Furthermore, JCL No. 11/2020 contains 15 chapters and 186 articles, and it regulates employment on the environment (Maharani, 2020). According to various laws and regulations in force in Indonesia related to employment that legal protection for workers is very important to be implemented consistently (Hamid, 2020:100, \& Hamid, 2021:544) as mandated by the Preamble to the 1945 Constitution. On the other hand, The urgency of JCL No.11/2020 is stated in the following considerations:

i. $\quad$ To realize the goal of establishing the Indonesian State Government and prosperous, just and prosperous Indonesian society based on Pancasila and the 1945 Constitution to fulfill citizens' rights to work and a decent life for humanity through copyright work;

ii. $\quad$ To be able to absorb Indonesian workers as widely as possible in the midst of increasingly competitive competition and the demands of economic globalization;

iii. To adjust various regulatory aspects related to the ease of protection and empowerment of cooperatives and micro, small and medium enterprises to increase the investment ecosystem and accelerate national strategic projects including improving the protection and welfare of workers;

iv. To protecti and empower of cooperatives and micro, small and medium enterprises, enhancing the investment ecosystem and accelerating national strategic projects, including improving the protection and welfare of workers scattered in various current sector laws, have not been able to meet the legal need for accelerated work copyright. necessary;

$v$. To change regulations relating to the convenience, protection and empowerment of cooperatives and micro, small and medium enterprises, enhancing the investment ecosystem, and accelerating national strategic projects, including improving the protection and welfare of workers are carried out through changes to sector laws that do not yet support the realization of synchronization. in guaranteeing the acceleration of work creation, it is necessary to have a legal breakthrough that can comprehensively solve various problems in several laws into one law; and

vi. Based on the considerations as referred to the points $a, b, c, d, e$ and it is necessary to form a Labor Law on JCL No.11/2020.

Furthermore, to achieve goals in the field of employment in Indonesia, JCL No.11/2020 amended, abolished, and stipulates new regulations in four laws, and one of them is the Manpower Law No.13/2003 (JCL No.11/2020 article 80). However, the planning, discussion, and ratification of this law has crucial problems when viewed from the methodological aspect, paradigm and substance of regulation in the policy sector. This law has ignored the principles of sustainable development so that it has the potential to give birth to complex hyper-regulated problems. According to experts from Fakultas HukumUGM (2020) that overly regulated and overlapping problems that occur in the regulation of fields related to development and investment will not be resolved. Thus, several things are needed as follows: (a). There are about 500 derivative regulations, and (b). The process of drafting laws and regulations concerning the problems of the lives of many people requires a careful and participatory process involving various related parties. community elements (Fakultas Hukum UGM, 2020).

In this context, it is even more ironic that after the joint approval of the DPR and the President in the plenary session, the text of JCL No.11/2020 underwent a substantial change. This happened both while still in the DPR RI and after being submitted to the President. The most amended provisions by the DPR in JCL No.11/2020 against the Manpower Law No.13/2003, namely that there are 73 (seventy-three) articles that are affected. This is a deviation as regulated in Article 1 paragraph (1), paragraph (2), paragraph 3, paragraph (11) and Article 72 of Law Number 15 of 2019 concerning Amendments to Law 12 of 2011 concerning the Establishment of Legislation as follows:

i. $\quad$ Article 1 paragraph (1), paragraph (2), paragraph 3 and paragraph (11) are as follows: Formation of Legislation is the making of Legislation which includes the stages of planning, preparation, discussion, ratification or stipulation, and promulgation (paragraph 1); Legislation is a written regulation that contains legally binding norms and is established or stipulated by a state institution or competent official through the procedures stipulated in the Legislation (paragraph 2); Laws are Legislative Regulations established by the House of Representatives with the joint approval of the President (paragraph 3); and Academic Manuscripts are texts of the results of research or legal studies and other results of research 
on a particular problem that can be scientifically accounted for regarding the regulation of the problem in a Draft Law, Draft Provincial Regulation, or Regency/City Regional Regulation Draft as a solution to the problem. and the legal needs of the community (paragraph 11);

ii. Article 72 regarding the explanation of article by article of Law Number 15 of 2019 concerning Amendments to Law No. 12 of 2011 concerning the Formation of Legislative Regulations.

In relation to legal norms, Kelsen (2009:124) states that the unity of legal norms is based on the fact that the creation of the norm which is lower - is determined by others - the higher - the creation is determined by higher norms, and this regression terminated by the highest, the basic norm which, the supreme reason for the validity of the entire legal order, is its unity . Thus, the lowest legal norms must adhere to the higher legal norms, and the highest legal rules (such as the constitution) must adhere to the most basic legal norms or grundnorm (Kelsen,2009:124). According to Farida (1998:25), legal norms have a relative validity period (rechkracht) because the validity period of a norm depends on the legal norms above it, so that if the legal norms above it are revoked or deleted, then the legal norms that exist beneath it is pulled out or erased too.

Thus, there are changes in the substance of regulations in several regions, there is moderation of articles in JCL No.11/2020 which look advanced, but in certain areas they tend to cause problems. . Some examples related to JCL No.11/2020 are as follows:

i. There are contra in the legislative process which is carried out formally by the government and the legislature, and the nuance of this law is very much desired by the legislators so that it has an impact on neglecting public involvement, both during the process of formation up to the formation and enactment of this law. which usually must be based on the principle of justice (Voermans et.al.,:2015:279-294). As the Unitary State of the Republic of Indonesia (Negara Kesatuan Republik Indonesia/NKRI) as state administrator is prepared based on constitutional law (Staatsrecht) as a form of positive law that defines the relationship between various institutions in a country, namely the executive, legislative and judiciary (Hendratno \& Sihombing,2021). Despite the implementation of a democratic system, Indonesia has experienced a democratic system change from a Liberal Democracy to a Pancasila Democracy. Pancasila is rooted in the values and personality of the nation itself inherent in the identity of the Indonesian nation (Hendratno \& Sihombing).

ii. As a result, the absence of a blueprint for the formation of regulations related to the omnibus model, the technical discussion becomes chaotic and only follows the wishes and interests of the legislators and legislators. Violations in the legislative process occur in at least three things, among others: discussions that are carried out in a hurry, not transparently and without the participation of the wider community, for example community organizations, labor, academics and other stakeholders. This is in conflict with Article 18 of Law No. 12 of 2011 requires that the drafting of laws takes into account the aspirations and legal needs of the wider community (Fakultas Hukum UGM ,2020:14 -17).

The formation of rules related to the omnibus model implemented in the formation of JCL No.11/2020 tends to completely ignore the prevalence of democratic practices. In democratic practice, it is stated that the legislators, the President and the Parliament - in the Presidential system - are an extension of the people's sovereignty. The president becomes the executor of the people's wishes. A government must work based on basic laws that bind and are based on the highest power (sovereignty) in a country. When that power has been granted, the government is obliged to obey it and the concept of limiting power pinned by the state so that the government can pay attention to the wishes of the people as a source of sovereignty in exercising its authority.

Based on the various descriptions above, the interpretention and the urgency of the Job Creation Law No. 11 of 2020 (JCL No. 11/2020) can be concluded that JCL No. 11/2020 is the latest labor law applicable in Indonesia and the government has simplified various regulations. related to labor laws and regulations using an omnibus law system approach. In principle, JCL No.11/2020 aims to create the widest possible job opportunities for the people of Indonesia as mandated by the Preamble to the 1945 Constitution as a source of legal and moral ideals that must be upheld in the context of fulfilling the right to a decent living through ease of living, business and protection of Micro, Small and Medium Enterprises, and Medium Enterprises (MSMEs) and cooperatives. On the other hand, the aim of the government to enact this law is to improve the investment ecosystem, ease of doing business, increase worker protection and welfare, and accelerate national strategic projects.

\section{The Position of Labor in Indonesian Labor Law}

The purpose of the formation of Job Creation Law Number 11 of 2020 (JCL No.11/2020) is contained in Article 80 which reads: that in order to strengthen protection for workers and increase the role and welfare of workers in supporting the investment ecosystem, this law changes, removes, or sets new regulations for several provisions which is regulated in 4 (four) Laws namely: (a) Manpower Law No. 13 of 2003, (b) SJSN Law No. 40 of 2004,(c) BPJS Law No. 24 of 2011,and (d) UU PPMI No. 18 of 2017. Then, Article 59 of Manpower Law 13/2003 was amended and did not contain the previous provisions regulating the period of a specific time work agreement (PKWT), a maximum of 2 (two) years and can be extended 1 (one) time for a maximum period of 1 (one) year. The position of labor in JCL No.11/2020), especially in the field of manpower, is the subject matter for a more comprehensive study by researchers which includes a juridical review, the position of labor, and the implications of this law on workers in labor law in Indonesia which covers labor issues. foreign workers (TKA), fixed time work agreement (PKWT), outsourcing, working time, wages, termination of employment (PHK), social security and severance pay. 
The position of labor in JCL No.11/2020), especially in the field of manpower, is the subject matter for a more comprehensive study by researchers which includes a juridical review, the position of labor, and the implications of this law on workers in labor law in Indonesia which covers labor issues. foreign workers (Tenaga Kerja Asing/TKA), fixed time work agreement (PKWT), outsourcing, working time, wages, termination of employment (PHK), social security and severance pay as follows:

Table 1: The Position of Labor in Indonesian Labor Law

\begin{tabular}{|c|c|c|}
\hline No & $\begin{array}{l}\text { The Position of Labor } \\
\text { in Indonesian Labor } \\
\text { Law }\end{array}$ & $\begin{array}{l}\text { Manpower Law No.13/2003 applies } \\
\text { prior to the enactment of Law } \\
\text { No.11/2020 }\end{array}$ \\
\hline 1 & $\begin{array}{l}\text { Foreign } \\
\text { (TKA) }\end{array}$ & $\begin{array}{l}\text { Foreign workers (TKA) can be } \\
\text { employed in Indonesia only in a } \\
\text { working relationship for a certain } \\
\text { position and for a certain time and is } \\
\text { regulated in Manpower Law Number } \\
13 \text { Year } 2003 \text { concerning (Manpower } \\
\text { Law 13/2003) Articles } 42 \text { to Article } \\
49 \text {. } \\
\text { Manpower Law 13/2003 Article } 42 \\
\text { has: "Every employer who employs } \\
\text { foreign workers must have a written } \\
\text { permit from the Minister or an } \\
\text { appointed official". } \\
\text { Then, Article } 49 \text { of Manpower Law } \\
\text { No.13/2003 regulates the provisions } \\
\text { regarding the use of foreign workers } \\
\text { and the implementation of education } \\
\text { and training for companion workers is } \\
\text { regulated by a Presidential Decree. }\end{array}$ \\
\hline
\end{tabular}

Job Creation Law No. 11 of 2020

JCL No.11/2020 regulates the granting of permits to use foreign workers by government agencies. Revision of Manpower Law No.13/2003 Article 42 becomes: Every employer who employs foreign workers is required to have a plan to employ foreign workers which is approved by the Central Government. Provisions regarding certain positions and a certain time as referred to in the Revised paragraph of Manpower Law No.13/2003 Article 42 (4) and paragraph (5) shall be regulated in a Government Regulation. The provisions referred to in Article 42 paragraph (1) do not apply to: (a). directors or commissioners with certain shareholdings or shareholders in accordance with the provisions of laws and regulations, (b) diplomatic and consular employees at representative offices of foreign countries, or, (c). foreign workers required by the Employer in the types of production activities that have stopped due to emergencies, vocational, start-up companies (start-ups), business visits, and research for a certain period of time.

Then, this is regulated in Article 3 paragraph (1) a JCL No.11/2020 and its derivative regulations in the form of Government Regulation (PP) Number 34 of 2021 concerning the Use of Foreign Workers (TKA) as regulated in Article 1, Article 2 paragraph (1) and (2), Article 3 paragraph (1) a, Article 7 paragraph (1) c, Article 12 paragraph (1). In this case, Government Regulation Number 34 of 2021 allows foreign workers to occupy high and strategic positions in companies such as serving as directors or commissioners and from the technical side of the field, foreign workers can enter the vocational education sector and vocational training, the digital economy sector, and the oil and gas sector. contractor partnership contract.

\begin{tabular}{ll}
\hline 2 & Employment \\
Agreement Certain & \\
& Time (Perjanjian \\
& Kerja $\quad$ Waktu \\
& Tertentu/PKWT)
\end{tabular}

A work agreement for a specified JCL No.11/2020 removes the provisions on the time of the work agreement previously contained in Article 59 paragraph (1) point b of Manpower Law Number 13 of 2003. Initially, the time for PKWT was limited by law for a maximum of three years. Manpower Law 13/2003, Article 59 paragraph 1. The time limit for PKWT is now no longer regulated in law, but will be regulated by a Government Regulation as in JCL No.11/2020 Article 12 points 3 and 4 which amend Manpower Law No.13/2003 Article 56. "it is estimated that the completion will be in a time that is not too long and a maximum of 3 (three) years", and Article 59 paragraph (4) of Manpower Law No.13/2003 stipulates that PKWT is held for a maximum of two years and may only be extended once with a maximum period of one year

\begin{tabular}{ll}
\hline 3 Outsourcing & The company can hand over part of the \\
& implementation of the work to other \\
& companies through a work contracting \\
& agreement or worker/labor service \\
& provider made in writing which is \\
& regulated in Manpower Law \\
& No.13/2003 Articles 64 to 66.
\end{tabular}
Manpower Law No.13/2003 Article 64 and Article 65 are deleted.
In JCL 11/2020 that Manpower Law 13/2003 Article 66
paragraph (1) is also deleted. Manpower Law 13/2003 Article 66
paragraph (1) which is deleted contains that workers/ laborers
from companies providing worker/labor services may not be used
to carry out main activities or activities that are directly related to
the production process, except for supporting service activities or
activities that are not related. directly with the production process.

In JCL No.11/2020 it is changed to:

-The work relationship between the outsourcing company and the workers/laborers. It employs is based on a work agreement made in writing, either a work agreement for a specified time or an indefinite work agreement; 
-Protection of workers/labor ,wages and welfare, working conditions and disputes that arise are carried out at least in accordance with the provisions of statutory regulations and become the responsibility of the outsourcing company;

-In the event that an outsourcing company employs workers/laborers based on a work agreement for a specified period of time as referred to in paragraph (1), the work agreement must require the transfer of rights protection for the worker/laborer in the event of a change in outsourcing company and as long as the object of work occurs still there;

(a).The outsourcing company as referred to in paragraph (2) shall be in the form of a legal entity and must comply with Business Licenses issued by the Central Government;

(b). Business licensing as referred to in paragraph (3) must meet the norms, standards, procedures and criteria stipulated by the Central Government; and

(c).Further provisions regarding the protection of workers/labor as referred to in paragraph (2) and Business Licensing as referred to in paragraph (4) shall be regulated in a Government Regulation.

\begin{tabular}{ll}
\hline 4 Working Time & Every employer is obliged to \\
& implement the working time \\
& provisions. According to Manpower \\
& Law No.13/2003, the provisions \\
& regarding working hours are regulated \\
& by a Ministerial Decree which is \\
& regulated in Article 77 to Article 85.
\end{tabular}
With regard to working time, JCL No.11/2020 does not make changes to the provisions. The provisions regarding working time in JCL No.11/2020 are still the same as the provisions in Manpower Law 13/2003. This means that in relation to Working Time, it is still as regulated in Manpower Law No.13/2003. In however there are two schemes: (a). 7 hours per day, 6 days per week; and (b). 8 hours per day, 5 days per week. Then, in addition, the implementation of working hours is regulated in a work agreement, company regulations, or a cooperation agreement, and what is changed is an exception regulated by Peraturan Pemerintah /PP. Overtime was changed, a maximum of 4 hours per day and 18 hours per week (previously 3 hours per day and 14 hours per week).

Regarding annual rest and leave, the provisions mentioned are the minimum requirements that must be given to workers. In JCL No.11/2020, the terms "rest" and "leave" are distinguished and what is removed is the provision on long rest (can be held according to company regulations). Furthermore, JCL No.11/2020 does not list a two-month long break following six consecutive years of service at the same company. While holidays and other leave are still permanent, there is no change.

5 Remuneration/Wages $\quad$ Manpower Law No.13/2003 has derivative regulations on wages, namely Government Regulation Number 78 of 2015 concerning Wages. Every worker/laborer has the right to earn income that meets a decent living for humanity as regulated in Articles 88 - 98. Manpower Law 13/2002 Article 88 in paragraph (2) includes: (a). minimum wages; (b).wage structure and scale; (c). overtime pay; (d). wages for not coming to work and/or not doing work for certain reasons;(e). norms and method of payment of wages; things that can be calculated with wages; and (f). wages as a basis for calculation or payment of other rights and obligations.

Manpower Law No.13/2003 Article 88 paragraph (3) reads as follows "The wage policy that protects workers laborers as meant in paragraph (2) includes: minimum wages; overtime pay; wages for absent from work due to absence; wages for absent from work due to other activities outside of work; wages for exercising the right to take time off from work; form and method of payment of wages; fines and deductions from wages; things that can
Some of the provisions in Manpower Law No.13/2003 amended by JCL No.11/2020 are as follows: 1. Types of wages minus the provisions of Article 88 paragraph (3) in Manpower Law No.13/2020 amended by JCL 11/2020. The minimum wage as referred to in Article 88C paragraph (1) and paragraph (2) is calculated using the minimum wage calculation formula. The formula for calculating the minimum wage as referred to in paragraph (1) contains a variable of economic growth or inflation, and further provisions regarding the minimum wage calculation formula are regulated in a Government Regulation. The difference in the standard for determining the minimum wage between Manpower Law 13/2003 and JCL No.11/2020 is the point of the need for decent living.

Manpower Law No.13/2003 states that one of the standards for determining the minimum wage is based on the needs of a decent life, but JCL No.1/2020 eliminates this point in the provisions for determining the minimum wage. In JCL 11/2020, the provisions in Manpower Law 13/2003 Article 92 are amended to read as follows: Entrepreneurs are required to arrange the structure and scale of wages in the company by considering the company's ability and productivity.

The structure and scale of wages are used as guidelines for employers in determining wages. Further provisions regarding the structure and scale of wages are regulated in a Government Regulation. This means that JCL.No.11/2020 eliminates the consideration of workers' tenure and delegates the structure and scale of wages based solely on the ability and productivity of the company. Then, Government Regulation (PP) Number 36 of 2021 concerning Wages in JCL No.11/2020 has been enacted, with the aim of updating several old policies, but there are also previous 
be calculated with wages; Wage structure and scale that is proportional; wages for severance pay; and wages for the calculation of income tax". Then, Article 92 of Manpower Law $13 / 2003$ on the provision of the structure and scale of wages for workers reads as follows "Employers arrange the structure and scale of wages by taking into account class, position, years of service, education and competence. Employers carry out regular wage reviews by considering the company's ability and productivity".

\begin{tabular}{ll}
\hline 6 & Termination \\
Employment \\
(Pemutusan \\
Hubungan \\
Kerja/PHK)
\end{tabular}

of Manpower Law No. 13/2003 regulates provisions related to termination of employment (PHK) which includes termination of employment (PHK) that occurs in business entities that are legal entities or not, owned by individuals, owned by partnerships or owned by legal entities, both private companies and legal entities. state-owned enterprises, as well as social enterprises and other businesses that have administrators and employ other people by paying wages or other forms of remuneration, and termination of employment may be carried out if this is unavoidable.

However, employers can only lay off workers / laborers after obtaining a stipulation from the industrial relations dispute settlement agency, and this is regulated in Manpower Law 13/2003 Articles 150 to Article 72. policies that remain in effect, including not coming to work due to absence such as sick workers, circumcision workers, menstruating female workers while sick so that they do not come to work, they are still paid.

Furthermore, JCLNo.11/2020 applies hourly-based wages and criteria for workers who will get wages under the scheme, namely part-time workers who are less than 30 hours a week, or less than7hours a day, and workers who are above At that time, formal or monthly wages were still applied and employers who did not pay wages to workers could be subject to fines and criminal sanctions.

Related to the derivation of JCL No.11/2020, including regulations related to layoffs, are Government Regulation (PP) Number 35 of 2021 concerning Specific Time Work Agreements (PKWT), Outsourcing, Working Time and Rest Time, and Termination of Employment (PHK). PP No 35/2021 Articles 36 to 59 regulate layoffs for companies and their workers. Based on Article 36 of the regulation, layoffs can occur for at least 15 reasons, including a company merging, consolidating, taking over, or separating a company and a worker who is unwilling to continue working relations or an employer is not willing to accept workers or laborers. Another reason is that the company carries out efficiency, the company closes due to continuous losses for two years, the company closes due to coercive circumstances, and others that require employers to pay severance pay and/or work period rewards.

PP 35/2021 regulates that workers' severance pay is only 0.5 times or 50 percent of wages as follows:

-Article 42 paragraph (2): In the event of a company takeover which results in a change in working conditions and the Worker/Laborer is unwilling to continue the Employment Relationship, the Employer can Terminate the Employment Relationship and the Worker/Laborer has the right to: severance pay of 0.5 (zero point five) times the provisions of Article 40 paragraph (2);

-Article 43 paragraph (1): Employers can terminate the Worker/Laborer because the Company is doing efficiency because the Company experiences losses, the Worker/Laborer has the right to: a. severance pay of 0.5 (zero point five) times the provisions of Article 40 paragraph (2);

-Article 44 paragraph (1):"Employers can terminate the Worker/Laborer for the reason the company closes because the company experiences continuous losses for 2 (two) years or experiences losses not continuously for 2 (two) years. then the Worker/Laborer is entitled to a severance pay amounting to 0.5 (zero point five) times the provisions of Article 40 paragraph (2)"; and

-Article 45 paragraph (1): Employers can terminate the Worker Laborer because the company closes due to force majeure, so the Worker/Laborer is entitled to severance pay of 0.5 (zero point five) times the provisions of Article 40 paragraph (2).

The new regulation revised Manpower Law 13/2003 by removing articles 167 and 184. JCL No.11/2020 also revised the types of social security provided to workers by adding job loss benefits. This provision revises Law Number 40 of 2004 concerning the National Social Security System. 


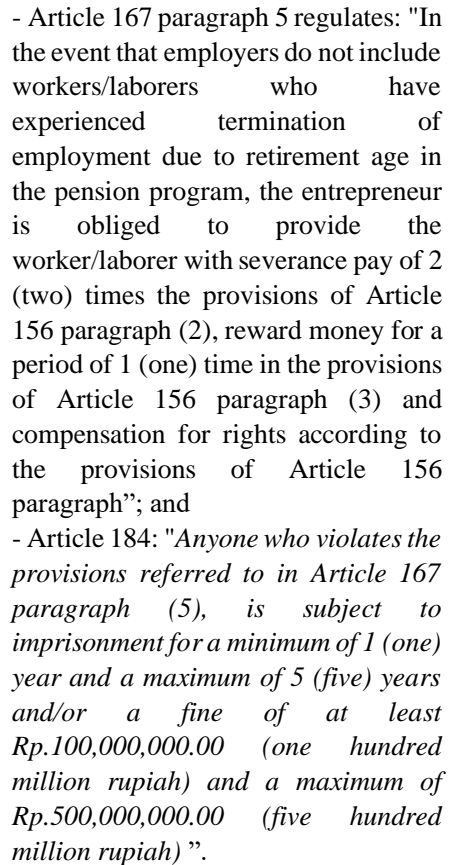

Based on table 1 it can be interpreted that JCL No.11/2020 amending, abolishing, or stipulating new regulations tends to be considered impartial and very counterproductive to manpower development efforts which are an integral part of the aims and objectives of manpower development based on Pancasila and the 1945 Constitution. Therefore, achieving the target of manpower development must actually be in line with national development, so that policies related to labor regulations that provide justice, certainty and benefits are needed. Then, with reference to the various descriptions above that at this time, the positioning of labors in the Indonesian Manpower Law, especially in JCL No.11/2020 tends to be powerless because JCL No.11/2020 has changed a number of articles in the Manpower Law No.13/2003. However, this has implications for the position of workers/laborers as mandated by the Preamble to the 1945 Constitution of the Republic of Indonesia Article 27 paragraph (2) stating that "every Indonesian citizen has the right to work and a decent living for humanity", Article 28D paragraph (2), states that: "Everyone has the right to work and receive fair and proper remuneration and treatment in an employment relationship." and Article 33 of the 1945 Constitution of the Republic of Indonesia, 3 paragraph (1) confirms that the economy is structured as a joint effort based on the principle of kinship.

Thus, legislators, the President and Parliament in the Presidential system in the context of implementing complete Indonesian human development and the development of Indonesian society as a whole must be consistently guided by the mandate of the Preamble of UUD RI 1945, article 27 paragraph (2), Article 28D paragraph (2), and article 33 of UUD RI 1945. This is the basis for the government and parliament in making policies on laws and regulations that simultaneously provide special protection to workers or laborers and employers. For this reason, the Government of Indonesia is expected to be able to formulate strategies and policies and to have comprehensive legislation, particularly labor law. This is aimed at increasing the dignity and self-respect of Indonesian workers in an effort to achieve a prosperous and equitable society both materially and spiritually.

\section{The Implication of Job Creation Law No. 11 of 2020 for Labor}

Accoding to the experts from Fakultas Hukum UGM (2020:14 -17) that the Job Creation Law No.11 of 2020 (JCL No.11/2020) does not solve the crucial problems contained in the Manpower Act 13/2003, such as the absence of informal workers such as homeworkers, domestic workers, or workers in non-standard employment relationships., and others. The partial revision carried out by JCL 11/2020 to the Manpower Law 13/2003 actually caused new problems that had a negative impact on labor protection so that it did not show the role and presence of the state as follows:(a).The loss of the provisions of the maximum time limit in the Specific Time Work Agreement (PKWT);(b).Elimination of the phrase "necessities for a decent living" as a reference for calculating the minimum wage which has an impact on shifting the concept of wage protection in a broad sense;(c).Elimination of restrictions on the types of work that can be outsourced; (d).Easier to terminate the labor (PHK), only through notification from employers to workers without prior negotiation;(e).JCL No.11/2020 also greatly reduces state control over employment relations;and (f).JCL No.11/2020 is not friendly to persons with disabilities, and this is counterproductive to the provisions of Law No. 8 of 2016 concerning persons with disabilities (Fakultas Hukum UGM,2020:14 -17)

The implication of the amendment of JCL No.11/2020 which is very significant for the field of manpower is that this law further increases the length of overtime working hours from a maximum of 3 hours a day and 14 hours a week to 4 hours a day and 18 hours a week. This changes Manpower Law No.13/2003 Law Article 78. Meanwhile, with regard to leave, it is regulated in the amendment 
to Article 79 of Manpower Law 13/2003 that leave or long rest is not mandatory and it does not regulate how long the long rest is given. In contrast to the provisions contained in Manpower Law No.13/2003, a long break is mandatory, at least 2 (two) months and implemented in the seventh and eighth year each one month for workers who have worked for 6 years continuously at the company. the same one. Amendments to Manpower Law No.13/2003 Article 88 of course have implications for regulating the wage system, the wage system policy is only aimed at realizing workers' rights to a life that is decent for humanity.

Previous provisions, Manpower Law No.13/2003 more explicitly mandated the government to establish a wage policy that protects workers. However, JCL No.11/2020 has amended Manpower Law No.13/2003 Article 88 paragraph (4) which stipulates that the determination of the minimum wage based on the needs of a decent life (KHL) by taking into account productivity and economic growth as well as further provisions regarding the wage policy are regulated in a Government Regulation (Thea, 2020). Furthermore, JCL No.11/2020 has deleted, amended and inserted several articles of Manpower Law No.13/2003 as follows:

i. $\quad$ Article 158 of Manpower Law No.13/2003, relates to serious mistakes that can be used as an excuse for termination of employment (PHK), and removes a number of provisions in Law 13/2003 which regulate the reasons for dismissal and the amount of compensation. An example is abolishing Article 162 of Manpower Law No.13/2003, which regulates that workers who resign on their own accord receive compensation for their rights and separation pay.

ii. The reasons for dismissal are due to a change in status, merger, consolidation, or change of ownership as regulated in Article 163 paragraphs (1) and (2) of Manpower Law No.13/2003. JCL No.11/2020 removes this provision along with the amount of severance pay that workers can receive, either one or two times the amount. The same thing also eliminates other provisions of dismissal, such as Article 166 which previously regulated layoffs because the worker died, the heirs were given severance pay compensation of 2 (two) times the stipulation.

iii. JCL 11/2020 inserts 13 articles in Manpower Law No.13/2003 covering Articles 61A, 88A, 88B, 88C, 88D, 88E, 90A, 90B, $92 \mathrm{~A}, 151 \mathrm{~A}, 154 \mathrm{~A}, 157 \mathrm{~A}$, and 191A. For example, Article 61A regulates that there is compensation for PKWT workers who have ended their contract. Article $88 B$ regulates that wages are determined based on the unit of time and / or unit of yield. Article 90B, states that the minimum wage does not apply to micro and small businesses which will be further regulated in a Government Regulation.

iv. JCL 11/2020 amends 1 article and inserts 5 articles in the SJSN Law. By amending Article 18 of the SJSN Law, UUCK 11/2020 adds a social security program, namely Job Loss Insurance or Jaminan Kehilangan Pekerjaan (JKP). Then the 5 articles inserted in the SJSN Law, in the articles 46A, 46B, 46C, 46D, 46E, essentially govern the implementation of the JKP program. "Workers/laborers who experience layoffs have the right to get JKP," reads JCL 11/2020 Article 46A paragraph (1). Still related to the JKP program, JCL 11/2020 amended 3 articles of the BPJS Law, namely Articles 6, 9 , and 42. Amendments to Article 6 paragraph (2) of the BPJS Law mandated BPJS Ketenagakerjaan to administer JKP. Article 42 states that the initial capital for the JKP program is Rp. 2 trillion from the state budget.

v. Regarding the employment cluster, JCL No.11/2020 amended articles 1, 51, 53, and 57 and inserted Article 89A in the PPMI Law. JCL No.11/2020 amends article 1 point 9 and Article 16 of the PPMI Law by changing the word "Minister", to "Central Government". UUCK No.11/2020 amended Article 57 of the PPMI Law which previously regulated various requirements for Indonesian Migrant Worker Placement Companies, and deleted Article 57 paragraph (1) of the PPMI Law which regulates the period of the Indonesian Migrant Worker Placement Company Permit or Surat Izin Perusahaan Penempatan Pekerja Migran Indonesia /SIP3MI (Thea,2020).

Furthermore, some amendments to articles that are very substance and are considered to be very controversial are contained in Chapter IV of JCL No.11/2020 and the implications are as follows: the following: (a).Article 59 of JCL No.11/2020 removes the rules regarding the period of a certain time work agreement (PKWT) or contract workers; (b) .Article 79 Workers' right to get two days of rest in one week which was previously regulated in Law 13/2003 is pared / cut, and this provision is regulated in article 81 point 23 of JCL No.11/2020 which amends Article 79 of Law 13/2003; (c). JCL No.11/2020 changes policies related to wages of workers, and this provision is regulated in article 81 point 24 JCL 11/2020 which amends article 88 of Law 13/2003, and inserts 5 (five) articles in the article $88 \mathrm{~A}$, article $88 \mathrm{~B}$, article $88 \mathrm{C}$, article $88 \mathrm{D}$, and article $88 \mathrm{E}$ which regulates wage fixing; (d). Regulations regarding sanctions for employers who do not pay wages in accordance with the provisions are removed through the Job Creation Law, and this abolition is contained in article 81 number 29 JCL 11/2020 which abolishes Article 91 paragraphs (1) and ((2) and Article 90 of Manpower Law No.13/2003; and (d).The terms of dismissal as amended in JCL 11/2020 as stipulated in the article 81 point 58 and removing article 169 paragraph (1) and paragraph (2) as stipulated in Manpower Law No.13 / 2003, article 156 .

The amendment to the article which is very substance and is considered very controversial is contrary to the rules related to the legal meanings. Purbacaraka and Soekanto (1982:13-14) state that there are 9 (nine) kinds of legal meanings, namely: law as; science, discipline, rules, legal system, officers, decisions of the authorities, government processes, attitudes or behavior, and law as a chain of values. Then, Eugen Erhlich in Huijbers (1988) in Sihombing and Hamid (2020) state that the actual social norms that govern all aspects of society, namely living law and law are subject to certain social forces and positive law cannot be effective if it is released from conditions. social., because order in society is based on social recognition of the law and not because of its official application by the state so that only positive law that is in line with living law will prevail in society (Sihombing \& Hamid, 2020). Thus, if 
examined from a sociological legal aspect, empirically the existing regulations in JCL No.11/2020 tend to be very detrimental to labor and inequality between workers as workers compared to employers. Therefore, this condition will make workers as workers do not have a strong bargaining position in the labor law in Indonesia, for example in terms of conducting fair two-way negotiations.

From the results of a critical study on JCL No.11/2020, it can be found that the implication of this law for workers in Indonesia is that workers are threatened with not receiving severance pay. JSL No.11/2020 removes at least 6 articles regarding severance pay. As a result, workers are threatened not to receive severance pay when they resign, experience termination of employment (PHK), or die, and foreign workers (TKA) enter Indonesia more easily. The following are the results of a critical study on JCL No.11/2020:

i. Article 81 point 51 of the JCL No.11/2020 abolishes the provisions of Article 162 of the Manpower Law No.13/2003 which contains rules for replacing severance pay for workers who resign.

ii. JCL No.11/2020 article 81 point 52 abolishes the Manpower Law No.13/2003 article 163 related to the provision of severance pay in the event of layoffs due to changes in status, mergers, consolidations, or changes in company ownership.

iii. JCL No.11/2020 article 81 points 53 abolishing the Manpower Law No. 13/2003 article 164 which regulates the provision of severance pay in the event of termination of employment (PHK) due to the company experiencing continuous losses for 2 years or force majeure.

iv. JCL No.11/2020 article 81 points 54 abolishing the Manpower Law No. 13/2003 article 165 regarding the provision of severance pay in the event of layoffs due to a bankrupt company.

v. JCL No. 11/2020 article 81 point 55 abolishing the Manpower Act No. 13/2003 article 166 concerning the provision of severance pay to heirs if the worker or laborer dies.

vi. It is easier for foreign workers (TKA) to enter Indonesia. This is done through JCL No.11/2020 article 81 points 4 to 11 , amending and removing a number of rules regarding foreign workers in Law Number 13 of 2003 concerning Manpower. For example, in No.13/2003 the government abolished the obligation of written permission for entrepreneurs who want to employ foreign workers as stated in JCL No.11/2020 article 81 point 4. Previously, this obligation was contained in the Manpower Law No.13/2003 article 42 point 1 which reads "Every employer who employs foreign workers is required to have written permission from the minister or appointed official,". Instead, employers are only required to have a plan for the use of foreign workers, as stated in JCL No. 11/2020 article 81 point 4 of the Law which amends the Manpower Law No. 13/2003 article 42 of the Law to: "Every employer who employs foreign workers must have a plan for the use of foreign workers approved by the central government.".

Based on the various descriptions above, it appears that the implication of this labor law in Indonesia is that JSL No.11/2020 has removed at least 6 articles on severance pay. As a result, labors are threatened not to receive severance pay when they resign, experience termination of employment (PHK), or die, and on the other hand JCL No. 11/2020 tends to make it easier for foreign workers (TKA) to enter Indonesia. The implication of the entry of foreign workers is the narrowing of employment opportunities in the country so that it will lead to a potential increase in the number of unemployed.

With a total population of about 260 million people, Indonesia is the fourth most populous country in the world (after China, India and the United States), and Indonesia has a young population because about half of Indonesia's total population is under 30 years old (Indonesia Investments, 2021). Therefore No.11/2020 should be reviewed and revised so that its alignment with the workers in Indonesia can be more felt and applied as mandated by the preamble to the 1945 Constitution. Furthermore, the real work of the Indonesian government is expected to be able to improve additional employment opportunities and simultaneously continue to strive to improve the skills of local workers in order to be able to compete with foreign workers.

\section{Conclusions}

The Job Creation Law No.11 of 2020 (JCL No. 11/2011) is the latest and applicable labor law in Indonesia. JCL No.11/2020 can be interpreted as legislation relating to employment both before, during and after the work period with the aim of optimizing human labor in order to create equal employment opportunities, provide legal protection, create and improve the welfare of workers/labors and their families. and the absence of discrimination. However, ironically, JCL No.11/2020, especially in the field of employment, is considered to tend to ignore labor rights. In fact, this law was formed and passed away from the wishes of the people who adhere to the principles of democracy, where the people are the source of sovereignty owned by the state in exercising its authority. This is marked by the non-optimal involvement of the wider community during the process of drafting and enforcing it as a labor law in force in Indonesia. JCL No.11/2020 tends to negate a strong bargaining position in labor law in Indonesia, for example there is no opportunity for workers to negotiate with employers in terms of termination of employment (PHK) and also in other matters. This makes JCL No.11/2020 very potential to be used by employers against workers, carrying out arbitrary actions. Therefore, there is a need for a very substantial revision effort to JCL No.11/2020 based on the development of labor law which is in line with the mandate of the Preamble and the 1945 Constitution which is the basis for the government and parliament to make policies on laws. This aims to improve the dignity of Indonesian workers in an effort to create a prosperous, just, prosperous and equitable society both materially and spiritually. 


\section{References}

Amiruddin dan Asikin, H. Z. (2006). Pengantar Metode Penelitian Hukum, Jakarta:PT Raja Grafindo Persada,

André, M. H. (2019). The future of work: Trade unions in transformational. International Journal of Labour Research, International Labour Office, Geneva. https://labordoc.ilo.org/discovery/fulldisplay/alma 995050793402676/ 41ILO_INST :41ILO_V2

Thea, A.D.A.(2020). Mengintip Isi Klaster Ketenagakerjaan UU Cipta Kerja”,03 November 2020, https://www.hukumonline.com/ BBC News Indonesia. (2020). https://www.bbc.com/ indonesia/ indonesia-51542411

Fakultas Hukum UGM.(2020). Kertas Kebijakan Catatan Kritis Terhadap UU No 11 Tahun 2020 Tentang Cipta Kerja . Pengesahan DPR. https://rispub.law. ugm.ac.id

Farida, Maria. (1998). Ilmu Perundang-Undangan, Yogyakarta: Kanisius

Hakim, R.N..(2020).Undang-Undang Cipta Kerja Resmi Dinomori Jadi Undang-Undang Nomor 11 Tahun 2020, https://nasional. kompas.com.

Hamid, A. (2019). Protection Of Indonesian Domestic Workers: A Study Of Law No. 13 Of 2003 Concerning Labor. International Journal of Scientific \& Technology Research, 5-9. ISSN 2277-8616. https://www.ijstr.org/final-print

Hamid, A. (2020). Analysis of the Importance of Omnibus Law Cipta Kerja In Indonesia. International Journal of Scientific Research and Management, 236-250. https://doi.org/10.18535/ijsrm/v8i08.1la01

Hamid, A. (2020). Questioning the Leadership and Preferences of Regional Heads in Determining Minimum Wage. International Journal of Scientific Research and Management. 251-265. https://doi.org/10.18535/ijsrm/v8i08.1la01

Hamid, A. (2020). Anticipating the Escalation of Foreign Workers after the Enactment of the Job Creation Law: Indonesia Legal Perspective. International Journal of Sciences: Basic and Applied Research, 95-108. ISSN 2307-4531. https://gssrr.org/index. php/Journal OfBasic AndApplied/article/view/12067/5840

Hamid,A. and Hasbullah (2020)., The Implementation of criminal sanctions as ius puniendi : A case study of entrepreneurs paying below the minimum wage in Indonesia. International Journal of Research in Business \& Social Science , (21474478), 10(4), 535-548. https://doi.org/10.20525/ijrbs.v10i4.1259

Hendratno, E.T. and Sihombing,B.F.(2021). Dynamics of Development of Regional Government Law: Implications of the Implementation of Centralization and Decentralization in Indonesia. International Journal of Sciences: Basic and Applied Research, 163-182. ISSN 2307-4531. https://www.gssrr. org/ index.php/JournalOfBasicAndApplied /article/view/ $12224 / 5860$

Kharlie, A.T.(2020). Tiga Strategi Menyikapi UU Cipta Kerja - Kemaslahatan UU Cipta Kerja tak berbanding lurus dengan mudharat yang ditimbulkan". https://www.republika.id/posts/10869/tiga-strategi-menyikapi-uu-cipta-kerja

Ibrahim, J. (2008). Teori dan Metodologi Penelitian Hukum Normatif. Surabaya: Bayumedia,

Indonesian Center for Law and Policy Studies. (2020). Permasalahan Proses Legislasi UU Nomor 11 Tahun 2020 tentang Cipta Kerja. November 11. https://pshk.or.id/publikasi/lawmetric/permasalahan-proses-legislasi-uu-nomor-11-tahun-2020-tentang -cipta-kerja

Indonesia Investments. (2021). Pengangguran di Indonesia. https://www.indonesia-investments.com/id/keuangan/angka-ekonomimakro/pengangguran/item 255

Kelsen, H. (2009). General Theory of Law and State, Translated by Anders Wedberg. Massachusetts: Harvard University Printing Office Cambridge,

Komarudin, U. (2020). Polemik UU Omnibus Law Cipta Kerja. https://akurat.co/polemik-uu-omnibus-law-cipta-kerja?page=2\#

Kukuh, T. , \& Sukarmi, S. (2020). The Critical Study of the Omnibus Bill on Job Creation Based on John Rawls View on Justice. Unnes Law Journal, 6(2), 187-204. https://doi.org/ 10.15294/ulj.v6i2. 41709

Maharani,T..(2020).UU Cipta Kerja Berlaku, Ini Pasal-pasal Kontroversial di Klaster Ketenagakerjaan. https://nasional.kompas.com/read/2020/11/03/10285541/uu-cipta-kerja-berlaku-ini-pasal-pasal-kontroversial-di-klaster? page $=$ all

Marzuki,P. M. ( 2006). Penelitian Hukum. Jakarta: Kencana Prenada,

Moleong, L.J. (2004). Metodologi Penelitian Kualitatif, Bandung: PT.Remaja Rosdakarya

Notonagoro.(2015). Hak Dan Kewajiban Warga Negara Indonesia Dengan UUD 45. Mahkamah Konstitusi Rrepublik Indonesia 11 Agustus. https://www.mkri.id/index.php?page =web.Berita\&id $=11732$

Nukhbatul, M., dan Aep, S.,.(2020). Omnibus Law and Problematics Labor In Indonesia. The 1st Proceeding International Conference And Call Paper Sultan Agung Islamic University. Unissula Press, 57-62. ISBN. 978-623-7097-74-7, ,http://jurnal.unissula.ac.id /index. php /oloc/article/ view/13422/5063

Peraturan Pemerintah (PP) Nomor 34 Tahun 2021 Tentang Penggunaan Tenaga Kerja Asing

Peraturan Pemerintah (PP) Nomor 36 Tahun 2021 tentang Pengupahan dalam Undang-Undang Cipta Kerja

Peraturan Pemerintah (PP) Nomor 35 Tahun 2021 tentang Perjanjian Kerja Waktu Tertentu), Alih Daya (Outsourcing), Waktu Kerja dan Waktu Istirahat, dan Pemutusan Hubungan Kerja

Purbacaraka, P. dan Soekanto, S.(1982), Sendi-Sendi Ilmu Hukum dan. Tata Hukum, Bandung: Alumni.

Pusat Studi Hukum dan Kebijakan Indonesia / PSHKI (2020). Permasalahan Proses Legislasi UU Nomor 11 Tahun 2020 tentang Cipta Kerja. https://pshk.or.id 
Sesa,T.D.A. (2016). Analisis Yuridis Kedudukan Dan Perllindungan Hukum Pekerja Rumah Tangga Dilihat Dari Perspektif Peraturan Perundang-Perundangan Bidang Ketenagakerjaan (Thesis). https://www.neliti.com

Sihombing,. B.F.,and Hamid, A. (2020). Impact of the Omnibus Law/Job Creation Act in Indonesia. International Journal of Scientific Research and Management, 266-281. https://doi.org/10.18535/ijsrm/v8i08.1la01

Soekanto, S. \& Mamudji, S. (2003). Penelitian Hukum Normatif: Suatu Tinjauan Singkat. Jakarta: PT. Raja Grafindo Persada, Supriyatna, I.\&Fauzi,A.(2020).Pasal-pasal di UU Cipta Kerja yang Disebut Merugikan Buruh. https://www.suara.com Undang Undang Dasar Republik Indonesia 1945

Undang-Undang Nomor 13 Tahun 2003 tentang Ketenagakerjaan

Undang-Undang Nomor 11 Tahun 2020 tentang Cipta Kerja

Undang-Undang Nomor 40 Tahun 2004 tentang Sistem Jaminan Sosial Nasional (UU SJSN)

Undang-Undang Nomor 24 Tahun 2011 tentang Badan Penyelenggara Jaminan Sosial (UU BPJS)

Undang-Undang Nomor 18 Tahun 2017 tentang Pelindungan Pekerja Migran Indonesia (UU PPMI)

Undang-Undang Nomor 15 tahun 2019 tentang Perubahan atas UU No. 12 Tahun 2011 tentang Pembentukan Peraturan PerundangUndangan

Undang-Undang Nomor 15 tahun 2019 tentang Perubahan atas UU No. 12 Tahun 2011 tentang Pembentukan Peraturan PerundangUndangan.

Voermans,W.; Napel, H.M., and Passchier,R. (2016). Combining efficiency and transparency in legislative processes. The Theory and Practice of Legislation3 (3), 279-294. https://doi.org/10.1080/20508840.2015.1133398

Publisher's Note: SSBFNET stays neutral with regard to jurisdictional claims in published maps and institutional affiliations.

\section{() (1)}

(C) 2021 by the authors. Licensee SSBFNET, Istanbul, Turkey. This article is an open access article distributed under the terms and conditions of the Creative Commons Attribution (CC BY) license (http://creativecommons.org/licenses/by/4.0/).

International Journal of Research in Business and Social Science (2147-4478) by SSBFNET is licensed under a Creative Commons Attribution 4.0 International License. 